Данијела Д. Добретић

danijela.m.dobretic@gmail.com

Андреј С. Радуловић

gbnovisad@gmail.com

Градска библиотека у Новом Саду
Стручни рад

UDK 025.2:027.022(497.113)

https://doi.org/10.18485/bibliotekar.2019.61.1.5

\title{
НАБАВНА ПОЛИТИКА ГРАДСКЕ БИБЛИОТЕКЕ У НОВОМ САДУ: ЦИЉЕВИ, КВАНТИТАТИВНИ И КВАЛИТАТИВНИ КРИТЕРИЈУМИ, ЗАКОНСКЕ РЕГУЛАТИВЕ И НАЧИНИ НАБАВКЕ
}

Сажетак: У раду је разматран проблем набавке књига у јавним библиотекама, с посебним освртом на набавку књига у Градској библиотеци у Новом Саду и моделе како се реализује овај важан сегмент у раду библиотеке, почевши од циљева набавне политике, квалитативних и квантитавних критеријума набавке и закона, смерница и стандарда на које се ослањамо у раду. Анализирана је и набавна политика у односу на старосну структуру становништва као и обухваћеност становништва Новог Сада чланством у Градској библиотеци у Новом Саду. Указано је, коначно, и на начине попуњавања фондова у Библиотеци, законске регулативе и скренута пажња на поједине проблеме с којима се библиотекари суочавају и како их превазићи.

Кључне речи: набавна политика, критеријуми набавке књига, принова књига, Градска библиотека у Новом Саду.

\section{Увод}

Набавна политика представља један од најзначајнијих елемената стратегије развоја сваке библиотеке. Мора да буде планирана тако да створи предуслове за успешно обављање културне, образовне и информационе функције Библиотеке. Такође, битно је напоменути да нам је намера да 
тежимо изједначавању и усаглашавању међусобних идеја и искустава, како би смо добили што сличнију методу и слику функционисања библиотека у Србији. Овим радом се трудимо да укажемо на проблеме Набавног одељења и њихово решавање, с посебним освртом на наша искуства у систему Градске библиотеке у Новом Саду.

\section{Циљеви набавне политике}

Циљ набавне политике је изграђивање, профилисање, развој и одржавање квалитетног, актуелног, богатог и универзалног библиотечког фонда, као и задовољење различитих потреба широког спектра корисника. То се постиже, с једне стране, праћењем издавачке продукције из области књижевности, науке и свих осталих хуманистичких дисциплина, затим праћењем развоја града и раста становништва, односно, праћењем корисничких потреба а с друге стране, и рационалним трошењем органичених финансијских средстава, водећи истовремено рачуна да се фондови, односно колекције, не оптерете непотребним насловима и примерцима.

Набавна политика јавних библиотека, па према томе и набавна политика Градске библиотеке у Новом Саду, своје упориште налази у следећим изворима:

1. Закон о библиотечко-информационој делатности у СР Србији из 2011. године;

2. IFLA/UNESCO смернице за развој јавних библиотека из 2001. године;

3. Стандард за јавне библиотеке у Републици Србији из 2009. године;

4. Стандарди за народне библиотеке из 1986. године;

5. Правилник о националним стандардима за обављање библиотечко-информационе делатности из 2013. године;

6. Принциии формираға фондова: уйравльате фондовима и ирочеgуре набавке (др Добрила Бегенишић, Народна библиотека Србије).

Набавка библиотечке грађе у Градској библиотеци у Новом Саду (у даљем тексту ГБНС) заснива се на следећим принципима:' планирање, доследност, универзалност, равномерност, евалуација и селекција, језик

Nevenka Perunović, Principi nabavne politike u bibliotekama (Beograd: Zadužbina Andrejević), 14. 
публикације, број примерака, континуираност, актуелност, перспективност, динамизам, еластичност, ажурност, координација, однос домаће и стране књиге.

Приликом набавке, у Набавном одељању ГБНС анализирају се потребе за датом публикацијом и води се рачуна о структури целокупног фонда, о структури фонда одређеног огранка, структури и броју становника и корисника, њиховим захтевима, као и захтевима стручних радника у огранку. Осим тога, води се рачуна о општим и посебним наставним плановима и програмима, како основних тако и средњих школа и факултета, о уделу одређених стручних група и типова публикација у укупном фонду и самој позајмици, расходованим књигама из одређене области на ревизијама (по принципу застарелости и оштећености публикација), типу и повезу публикације, али и о томе да се публикације набављају по најповољнијој цени и то путем јавне набавке - отворени поступак. На профилисање набавке у ГБНС значајно утиче и постојање других типова библиотеке у окружењу (Библиотека Матице српске, Централна библиотека на Универзитету, факултетских, специјалних), других релевантних установа и институција, као и њена мултиетничка средина и њој одговарајућа удружења, савети и сл.

Да би се конципирана набавна политика реализовала током читаве године се прати издавачка продукција (прегледањем издавачких каталога, база података, информација са интернета, сајтова издавача, интернет књижара, праћењем приказа на разним другим медијима, дезидерата, захтева корисника и библиотекара), ЦИП листе, билтен приновљених издања, библиографије и др. У одлучивању о профилу набавке, избору грађе, сврси, обиму и садржају колекција, као и о томе шта треба чувати, а шта отписати из фондова, учествује Комисија за набавку библиотечке грађе.

Циљ набавне политике библиотека треба да буде у складу са циљевима и функцијама јавних библиотека - формирање и одржавање квалитетног, актуелног, богатог и универзалног библиотечког фонда, као и задовољење различитих потреба великог броја корисника. Нажалост, сведоци смо времена где су култура и књига веома угрожене и условљене. Стандарде одређују рекламирани, неретко и безвредни аутори. Стручна литература постаје део подрума, а хийови су пребачени у прве редове наших полица. Тим пре, циљеви су далеко тежи и набавка књига подразумева апсолутни интегритет да бисмо, колико-толико, сачували стандарде квалитета књиге у нашем Фонду. 


\section{Квалитативни критеријуми набавке}

Квалитативни критеријуми набавке се огледају кроз сagpжај и $c \bar{u} p y \kappa \bar{u} y p y$ фондова библиотеке. У погледу садржаја јавна библиотека треба да свим категоријама становништва обезбеди широк распон библиотечко-информационе грађе с разних извора (штампаних и електронских), као и изворе на мањинским и другим језицима, разне врстие грађе, односно, $\oint о р м а \bar{u} е$ (књижна - монографске и серијске публикације; некњижна грађа - картографска, аудио-визуелна, електронска, мултимедијална, интернет и онлајн базе података, материјали на Брајевом писму и разноврсна друга некњижна грађа). Експанзивни развој нових технологија одређује и нове потребе потенцијалних корисника због чега се намеће и све већа потреба за имплементацијом нових медија (едукативног и забавног карактера), као и стварање различитих мултимедијалних колекција у библиотечким фондовима што ће у будућој набавци у ГБНС морати да постане један од њених приоритета. У погледу структуре ${ }^{2}$ библиотечки фонд ГБНС треба да има: највише $45 \%$ белетристике, тј. 35\% за матичне библиотеке; најмање $25 \%$ научне и научно популарне литературе; тј. може и до $40 \%$ јер је ГБНС матична библиотека; најмање $20 \%$ литературе за децу, а може и до $27 \%$ у библиотечким огранцима; референтну литературу од 3\% до 5\% за матичне јавне библиотеке као што је ГБНС; завичајну библиотечко-информациону грађу; мултимедијалну грађу (није прописано колико, најмање 200) која се формира као посебна збирка у свакој библиотеци; некњижну библиотечкоинформациону грађу (није прописано колико) као посебну збирку.

Структура куповином набављених и инвентарисаних књига у 2018. години у ГБНС: ${ }^{3}$

- 46,23\% белетристика, што је више од стандарда али због текућег расхода и ревизије фондова огранака ГБНС, показала се потреба за обновом дела наслова. Укупан фонд ГБНС има 49,77\% белетристике.

- 22,44\% стручна и научно-популарна литература, што је близу важећег стандарда. Набавком књига путем откупа Министарства културе Републике Србије овај проценат је повећан а приновљен је фонд са насловима

Bibliotekarsko društvo Srbije, Predlog Standarda za javne biblioteke u Republici Srbiji (Bibliotekarsko društvo Srbije, 2007), 5.

3 Градска библиотека у Новом Саду, Извешимај о раgу и йословаюу за 2018. іолину (Градска библиотека у Новом Саду, 2018), 22. 
који су скупи, до којих је тешко доћи због поступка јавне набавке књига итд. Укупан фонд ГБНС има око 22,9\% стручне и научно популарне литературе.

- 28,83\% литература за децу, што је у складу са стандардом. У укупном фонду ГБНС је било 23,91\% литературе за децу, а ту је битно рећи да је ГБНС матична библиотека за Јужнобачки округ, па је према томе и тај стандард задовољен.

- 2,5\% референсна литература а у укупном фонду ГБНС је 3,42\%.

\section{Квантитативни критеријуми набавке}

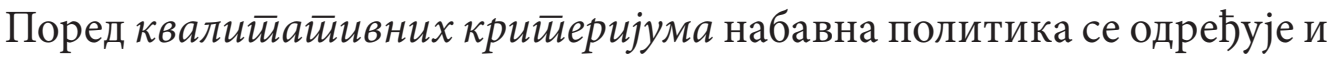

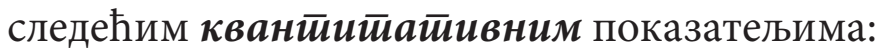

a) Број књиїа у фонду библиоиечкої оїранка се одређује и према броју становника насеља, односно, према категоријама јавних библиотека (стари и новоусвојени стандарди из 2010. године се углавном поклапају). Следећа табела ${ }^{4}$ приказује колико књига треба да има библиотечки фонд јавне библиотеке у односу на укупан број становника:

Табела бр. 1: Категорије јавних библиотека

\begin{tabular}{|c|c|c|c|}
\hline Категорија & $\begin{array}{c}\text { Број становника } \\
\text { за подручје: }\end{array}$ & $\begin{array}{c}\text { бр. књига по } \\
\text { становнику }\end{array}$ & почетни фонд \\
\hline VI & преко 100.000 становника & 1,5 & $>150.000$ \\
\hline V & $60.000-100.000$ становника & 1,5 & 150.000 \\
\hline IV & $35.000-60.000$ становника & 1,5 & 90.000 \\
\hline III & $20.000-35.000$ становника & 2 & 70.000 \\
\hline II & $10.000-20.000$ становника & 2 & 40.000 \\
\hline I & $5.000-10.000$ становника & 2,5 & 25.000 \\
\hline
\end{tabular}

Према IFLA/UNESCO смерницама за развој јавних библиоиека ${ }^{5}$ годишња стопа набавке књига за средине са преко 50.000 становника износи

4 Bibliotekarsko društvo Srbije, Predlog Standarda za javne biblioteke u Republici Srbiji (Bibliotekarsko društvo Srbije, 2007), 5.

5 IFLA/UNESCO smernice za razvoj javnih biblioteka (Beograd: Narodna biblioteka Srbije, Biblioteka grada Beograda, 2005), 47. 
0,20\%, односно 200 књига на 1.000 становника годишње. Према последњем попису становништва из 2011. године Нови Сад и приградска насеља (341.625 становника) и Сремски Карловци (8.750 становника) укупно имају 350.375 становника, што би значило да годишња набавка, према овим смерницама на годишњем нивоу треба да буде 70.075 књига.

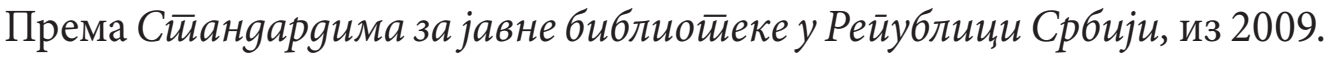

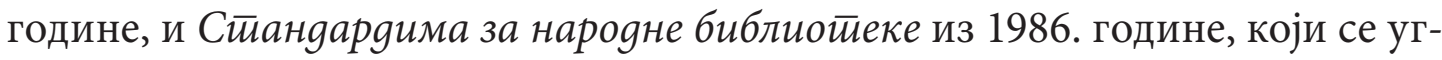
лавном поклапају, књижни фонд, у насељима већим од 100.000 становника, треба да износи 1,5 књига по становнику ${ }^{6}$, док су препоруке UNESCO-а 1,5-2,5 медијске јединице по становнику 7 . По тим препорукама, за 350.375 становника, колико има Нови Сад, он би требало да буде око 525.560, односно, 700.750 библиотечких јединица.

Нови Сад је град који се последњих година интензивно развија. Нека насеља су нагло нарасла, тако да би требало да се сразмерно том броју повећа и библиотечки фонд у њима. Највећи раст становништва је забележен у Ветернику, Футогу, Сремској Каменици и Каћу. У осталим огранцима величина фонда не одступа у већој мери од величине предвиђене стандардима (у случају Градске библиотеке у Новом Саду у питању је бројка од 1,3 књиге по становнику). Овде треба напоменути да се у пракси често догађа да неки огранак који се налази у мањем месту има већи број чланова од огранка у насељу са више становника. Зато ће и убудуће огранци са више чланова добијати више књига да би се испоштовала сразмера са бројем чланова.

Библиотечки огранци у градском језгру, с једне стране, имају проблема са смештајем, док су, с друге, фондови делом неактуелни, делом похабани. Ти проблеми се морају решавати редовним обављањем прописаних ревизија, после којих треба обновити и допунити њихове фондове.

\section{Набавна политика и старосна структура становништва}

Старосна структура становништва је параметар који одређује и старосну структуру библиотечких корисника, а самим тим и целокупну набавку библиотечке грађе (деца, средњошколци, студенти, запослени,

6 Лепосава Чукић и Ана Церанић, „Стандарди за народне библиотеке”, Заједница библиотека год. 15, бр. 1-4 (1986): 57.

7 IFLA/UNESCO smernice za razvoj javnih biblioteka. (Beograd: Narodna biblioteka Srbije, Biblioteka grada Beograda, 2005), 45. 
пензионери...). Приликом набавке библиотечке грађе за поједине огранке води се рачуна да она буде у складу са структуром и бројем свих старосних категорија чланства у огранцима ГБНС, са њиховим општим и посебним потребама и интересима, чиме са постиже и рационалност у набавци, али се, истовремено, постиже и задовољавање прописаних стандарда у погледу структуре одређене врсте фондова: белетристика за омладину и одрасле, литература за децу, научна и научно-популарна литература, референсна литература. Према последњем попису становништва деца од 0 до 14 година чине $15 \%$ укупног становништва новосадске општине, средњошколци и млади од 15 до 19 година чине 7\%, млади од 20 до 29 година (студенти и други) чине $15 \%$, од 30 до 59 година има око $43 \%$ и преко 60 година има $20 \%{ }^{8}$

\section{Обухваћеност становништва Новог Сада чланством у ГБНС и набавна политика}

Према важећим стандардима број корисника учлањених у општинску библиотеку је најмање $10 \%$ од укупног броја становника на територији општине. Укупна обухваћеност становништва је 7,51\% уписаних корисника у ГБНС. ${ }^{9}$ На обухваћеност, поред броја књига, утиче више фактора (величина и адекватност простора, локација, радно време, врсте и квалитет услуга, кадрови, културне потребе, образовни ниво итд.), због чега и следи да у свим библиотечким огранцима није обухваћен подједнак проценат становништва библиотечким чланством.

\section{б) їодишњи расти фондова}

Минимални стандард за годишњу принову књига износи 5\% у односу на укупан фонд ${ }^{10}$, који се у ГБНС последњих неколико година, углавном, успева постићи. Уколико је годишња набавка мања, застарелост фонда расте. Према препорукама које је изнео проф. др Конрад Умлауф, ${ }^{11}$ са Хумболт универзитета у Берлину, у оквиру предавања и радионице о набавној

\footnotetext{
Zavod za statistiku, Struktura stanovništva po starosti, http://www.stat.gov.rs

9 Mira Miljković, Danijela Dobretić i Zdenka Valent-Belić, Nabavna politika i stanje fondova u Gradskoj biblioteci u Novom Sadu (Novi Sad), 26.

10 Чукић и Церанић, „Стандарди за народне библиотеке”, 59.

11 Nabavna politika - radionica, prof. dr Konrad Umlauf - Goethe Institut Beograd, 2005. https:// www.nb.rs/view_file.php?file_id=1105
} 
политици јавних библиотека на Гете институту, ако би годишња набавка била по предвиђеним стандардима, за 10 година би требало обновити пола фонда, а за 15 година комплетан фонд. Треба подсетити да је, према општем консензусу стручњака, за кориснике атрактивнији мањи, али актуелнији фонд, као и да се мали број нових медија у великим фондовима тешко запажа, односно ако је премало нових медија, фонд застарева. Што се тиче минимално препорученог стандарда да се укупан фонд годишњом приновом увећа за 5\% нових медијских јединица, он се, као што је наведено, последњих година набавке у ГБНС, углавном, успева достићи, пре свега зато што је укупан фонд књига мањи него што препоручују сви наведени стандарди па и овај кога ми пратимо.

\section{в) обрит фонgа}

Према стандардима библиотечки фонд треба да се обрне најмање два пута годишње. По извештајима ГБНС цео фонд није се обрнуо један пут (нпр. почетни фонд у 2018. години био је 515.549 а број прочитаних књига је 429.022, позајмљено је просечно само $83,22 \%$ фонда (односно обрт је био 0,8$).{ }^{12}$ Ту, међутим, постоји велика разлика међу огранцима. Највећи обрт се постиже у градским огранцима. Према подацима Матичне службе Народне библиотеке Србије обрт књижног фонда јавних библиотека у Србији у 2007. години је био 0,54, у Централној Србији 0,66, а у Војводини 0,41 . Као што се види, обим коришћења књига у јавним библиотекама је изразито и забрињавајуће низак и представља озбиљан разлог за темељно преиспитавање целе мреже, као и сваке појединачне библиотеке. Овакво мишљење изражено је и у оценама Матичне службе НБС, према којима је остваривање основне функције јавних библиотека у великој мери угрожено, с обзиром на то да је овакво стање присутно дужи низ година. Према тим оценама „разлози због којих обрт књижног фонда у јавним библиотекама заостаје више од три пута за стандардном величином треба тражити, пре свега и у највећој мери, у знатном броју неактуелних и корисницима непотребних књига и у поремаћају у редовној, континуираној годишњој попуни фондова”. Овоме треба додати да на обим коришћења утиче старост фонда и његово физичко стање (похабаност), неадекватан смештај (високе и сабијене полице, сабијене књиге на њима, премален, влажан, скучен, неосветљен и неатрактиван простор, недовољна обрада, неразно-

12 Miljković, Dobretić i Valent-Belić, Nabavna politika i stanje fondova u Gradskoj biblioteci u Novom Sadu, 30. 
врсност медија, дугачак рок позајмљивања, број књига који се одједном позајмљује неком кориснику, неодговарајуће радно време, локација, али и врсте, број и ниво других услуга које се у библиотекама нуде.

За ГБНС би се могло рећи (и закључити) да је остваривање њене основне функције угрожено, пре свега 4-5 пута мањим простором од потребног за централну зграду, а за библиотечке огранке 1-2 пута. Поред тога што је премален, постојећи простор је и неадекватан, углавном влажан и неатрактиван, фондови су сабијени на збијеним полицама које сежу до плафона, па се књиге нити виде нити их је могуће дохватити. Други проблем је застарео фонд који се ретко отписује и који се не издаје, затим то у огранцима нема ничег осим књига, дневне штампе и часописа, што није довољно да би библиотека била место какво данас треба да буде у коме радо и из више разлога дуже бораве све структуре и старосне групе њених корисника.

У јавним библиотекама је веома значајно и мерење квойе расйоложивостии неког наслова. Под тим се мисли на регистровање учесталости позајмљивања неког наслова, тј. присуства-расположивости у фонду у датом тренутку.

Обрт фонда обрнуто је пропорционалан расположивости, односно, што је краћи рок позајмљивања расположивост је већа, а обрт фонда чешћи, односно, што је дужи рок позајмљивања расположивост је мања, а и обрт фонда је мањи. У свим огранцима ГБНС рок изнајмљивања је три недеље, уз толеранцију још једне недеље. Постоји, такође, препорука да се тражени наслови, чија заступљеност (недовољан број примерака) у фонду у неком периоду није довољна (када је актуелна нека лектира, када је неки наслов добио неку награду или неку медијску пажњу и сл.), позајмљују на краћи период (10-15 дана), али се то у ГБНС не примењује. Расположивост и обрт се умањују и када се истовремено једном кориснику изда већи број књига које он дуго не враћа и не долази по друге.

Информисање о недовољном броју примерака и ниској квоти расположивости неког наслова, врши се претраживањем Електронског централног каталога библиотеке, усменом комуникцијом између библиотекара Одељења за попуњавање фондова, Комисије за набавку и радника из огранака и путем достављања дезидерата. Сви ти захтеви се уносе у базу дезидерата која се ажурно води (унос нових захтева и брисање решених) и користи приликом сваке набавке или поделе књига. 


\section{і) искоришћеност̄ фонда}

Док се обрт фонда мери бројем укупно издатих публикација (задуживања), искоришћеност фонда се мери стиеиееном акииивирања тј. издавања неког наслова. У фонду постоје делови који се често траже и издају, који се траже и издају периодично, повремено, ретко или никако. Постоје препоруке да из фодова јавних библиотека треба уклањати наслове који током три године (па чак и током једне) ниједном нису коришћени, односно издати. У фондове, такође, не треба укључивати наслове за које се унапред зна да неће бити коришћени, док оне за које се претпоставља да ће бити мало коришћени треба набављати у минималним количинама и то за огранке у којима се претпоставља да ће бити тражени. Овом критеријуму би се у ГБНС морала обратити озбиљнија пажња, посебно због тога што би се њиховим излучивањем и неукључивањем у огранцима обезбедио простор за смештај нових и тражених наслова и медија.

\section{g) $\overline{\mathbf{u} р а ј н о с \bar{и} \bar{и} у б л и к а ц и ј а ~}$}

Овај критеријум односи се на њихово хабање и физичко стање. Према препорукама публикација може да издржи у просеку од 60 до 100 позајмљивања, поготово дечја књига и сликовнице (тачни подаци не постоје и не воде се ни у једној библиотеци). ${ }^{13}$ Због тога се приликом набавке веома води рачуна о повезу публикације. Када год је то могуће, купују се издања у тврдом повезу и шивена, уместо брошираних и лепљених. Међутим, за већи део наших фондова може се рећи да су у лошем физичком стању јер је чак око 70\% фонда старије од 10 година, што се одражава и на обрт фонда и на број корисника. ${ }^{14}$

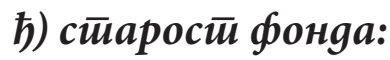

Према већини препорука и мишљења фондови застаревају после 10-15 година. По неким мишљењима, након 7 година, или мање, половина знања у неким областима застарева (медицина, техника, технологија и сл.), изузев класичних дела из области књижености или из неких обла-

13 Nabavna politika - radionica, prof dr Konrad Umlauf - Goethe Institut Beograd, 2005.

14 Miljković, Dobretić i Valent-Belić, Nabavna politika i stanje fondova u Gradskoj biblioteci u Novom Sadu, 33. 
сти као што су филозофија, уметност, као и општи постулати природних и друштвених наука. Према тим ставовима просечна старост половине фонда требало би да буде 5-10 година (што се највише односи на стручни фонд), док се граница застарелости за белетристику помера до 15 година, када би, нарочито због физичког стања, требало обновити цео фонд. Од овога су изузети фонд Завичајне збирке, као и издвојени завичајни кутак појединачних огранака. У неким случајевима потребно је да се у фонду чувају и старије и мање коришћене књиге, као посебне целине које нису непосредно доступне корисницима, које имају текућу или будућу употребну вредност и које се не могу заменити или наћи у неком другом формату. То су, такође, обично посебне тематске целине које се користе редовно, иако у ограниченом обиму (приручници) и књижевна дела чији су тиражи распродати. Књиге са застарелим информацијама, или оне које су похабане, оштећене, или их је у много примерака (неактуелна лектира) треба уклањати у текућим расходима, затим у парцијалним или редовним ревизијама. Укупна просечна старост књижног фонда ГБНС је већа од 20 година, јер се његова старост у огранцима креће од 20 до 30 година. ${ }^{15}$ Излучивање књига из фондова би требало спроводити према важећем Уйуйстиву о ревизији и оййису библиойечке іррађе (Закон о библиотечко-информационој делатности). Комисија за набавку књига је препоручила да се, уколико је могуће, набаве обновљена издања неких наслова (класици, дечја литература...) и да се на тај начин, поред расхода, утиче на просечну старост фонда ГБНС.

\section{Начини набавке књига}

Најважнији проблем сваког пабавног одељења, у систему библиотеке, јесте набавка или принова публикација. Књиге у библиотеку могу стићи на следеће начине:

1. Куповином, путем јавне набавке (у нашем случају средствима града Новог Сада, нашег оснивача);

2. Путем откупа (годишњег републичког откупа);

3. Путем поклона (донацијама грађана);

4. Преко ЛОП-а - локалног обавезног примерка;

15 Miljković, Dobretić i Valent-Belić, Nabavna politika i stanje fondova u Gradskoj biblioteci u Novom Sadu, 34. 
5. Разменом (међубиблиотечка размена књига и размена са другим институцијама сличног карактера).

Јавна набавка је најтежи и најспорији начин добављања књига у свакој библиотеци. Састоји се из потраживања средстава из буџета и подразумева унапред урађене елементе као што су провера изводљивости набавке, прикупљање понуда, организовање тендера и избор понуда. Уколико све протекне како треба, што не мора да буде случај, књиге долазе у Библиотеку најмање неколико месеци по њиховој реалној потреби. Куповина као плански вид набавке, најзначајнији је начин попуњавања фондова. Током 2018. године у Градској библиотеци у Новом Саду куповином је обезбеђено 57,08\% приновљених публикација. ${ }^{16}$

Откуп Министарства културе и информисања РС је драгоцен начин набавке публикација, нарочито по новом моделу по ком библиотеке имају прилику да утичу на избор понуђених наслова и број примерака. Ту се води рачуна да се набављају скупља и вреднија издања, на чију се куповину из буџетских средстава теже одлучује, као и издања до којих је теже доћи због захтевног поступка јавне набавке приликом куповине књига. Последњих година уведен је модел са обавезним йримерком, тј. напреднији систем по узору на некадашњи обавезни примерак. Компетентна комисија, у складу с естетско-образовним стандардима, бира вредне наслове, и то је исправан инструмент државе да би се спровела квалитетна културна политика. Библиотекари сами унапред, разматрају шта ће бити обавезујуће, а шта неће, па тако и набављају књиге пре откупа, плански и систематично. Систем је практичан, лако се примењује, број издања који су обавезујући чини $40 \%$ од укупног броја одабраних публикација, односно исто толико од опредељених средстава. Књиге које су обележене звездицама у табелама су књиге које свака библиотека добија, без права на замену, и које је Комисија изабрала као наслове који су релевантни за примерен развој читалачке публике. У питању је, углавном, стручна литература, релевантна поезија, као и озбиљна прозна литература. Откупом је 2018. године приновљено 8,68\% фонда Градске библиотеке у Новом Саду.

Поклони су, с друге стране, доста практични за принову, не коштају ништа, велики број књига долази овим путем сваке године, али то није планска обнова фонда. Проблем везан за поклоне је недостатак простора, људства и времена. Сваки поклон мора се пажљиво прегледати, па ако је

16 Gradska biblioteka u Novom Sadu, Izveštaj o radu i poslovanju za 2018. godinu, 22. 
задовољавајућег квалитативног и естетског критеријума, приступити бази и дезидератима те му пронаћи место и сврху у систему огранака Градске библиотеке у Новом Саду. Поклони могу бити везани за одређене огранке, њима поклоњени и намењени (у нашем случају двадесет и шест огранака) или општи, доступни сваком огранку који има потребу за њима. Током 2018. године у Градску библиотеку у Новом Саду пристигло је 27,47\% поклона, а у фондове се укључују у складу са наведеним општим принципима и критеријумима набавке.

Локални обавезни примерак или ЛОП обавезује издаваче да библиотеци града у којем живе доставе обавезан примерак свих нових наслова. Треба рећи да се ово правило ретко поштује, иако подразумева законски акт, али, исто тако, додати да не постоје предвиђене санкције за непоступање по том акту. Тако је 2018. године ЛОП-ом приновљено 0,48\% публикација у ГБНС.

Међубиблиотечка размена подразумева сарадњу између библиотека и манифестује се периодичном разменом књига. Вишкови једне библиотеке понекад су неопходни за фонд других библиотека. Такође, неке библиотеке, као у овом случају Градска библиотека у Новом Саду имају сопствену издавачку делатност и врше размену издања с другим библиотекама. На овакву врсту прибављања књига треба посебно обратити пажњу будући да се неке књиге више не могу набавити куповином. Састављају се спискови са вишковима и шаљу другим библиотекама на одабир. Након завршених захтева књиге се упућују тамо где су потребне. ГБНС је 2018. године разменом добила 0,08\% књига.

\section{Закључак и предлози}

Набавна политика ГБНС и њени критеријуми ће се и у наредном периоду усклађивати са актуелним националним и међународним стандардима и осталим актима који регулишу и дају препоруке за набавку библиотечке грађе за јавне библиотеке. Такође, набавка ће бити у складу са стањем фондова у погледу његове величине - структуре, актуелности - старости, као и са захтевима и потребама тренутних али и потенцијалних корисника, што ће се редовно пратити и анализирати. У складу са стратегијом развоја јавних библиотека као јавних информационих и културно-образовних сервиса локалне заједнице, један од приоритетних задатака ГБНС треба да буде ширење спектра услуга и примена нових технологија и дигитализације, као једног сегмента, у сваком библиотечком 
огранку. С обзиром на то да савремена јавна библиотека све више постаје важно место имплементације нових информационих техника и пружања разних информација и услуга корисницима, тако, поред информационе, на значају све више добија и њена образовна функција. Када одређујемо набавну политику према томе какво место ГБНС треба да има у систему образовања, треба назначити да она мора да буде оријентисана тако да прати развој образовног система како би се могле задовољити ученичке потребе које из њега проистичу. У том смислу, поред класичне потребе да се набавља прописана лектира набавка се мора усмерити и на одговарајуће врсте медија са едукативним садржајима који прате и допуњују нове технике учења. Задаци набавне политике ће, као и до сада, бити равномерно и равноправно праћење продукције из свих области људског знања са тежњом да се у фонду Библиотеке нађу што значајније и актуелније публикације, како у погледу садржаја тако и у погледу медија на коме су презентоване. У складу са тенденцијама савременог библиотекарства у свету, а да би се повећао број корисника, ГБНС треба да истраје у прављењу стратегије свог развоја (краткорочног и дугорочног) у оквиру кога ће, између осталог, промовисати и нови, савременији концепт своје библиотечке мреже, тј. својих огранака у њој. Огранци би, већ сада, требало да буду место сталног окупљања и боравка свих категорија становништва локалне средине. Да би то било изводљиво, нужно је и у градској и у приградској средини створити просторне услове за проширење услуга и смештај одговарајуће опреме за разне мултимедијалне садржаје (рачунари, телевизори, бежични интернет), што ће омогућити и повећање нивоа досадашњих услуга. Ово се посебно односи на приградске огранке којима такав концепт огранка, у коме ће корисници моћи садржајно да проводе своје слободно време, понајвише треба. Да би се нови медији и опрема што више и адекватније користили потребно је да библиотека обезбеди потребне услове за оспособљавање својих корисника путем одговарајућих курсева, упутстава или процедура од стране библиотечких радника, који и сами морају да буду довољно оспособљени. Поред тога корисницима морају да буду доступни и разни библиотечки инструменти информисања. Библиографије (опште и посебне) и регистри, као инструменти информисања заступљени су у мери у којој су потребни за одређена истраживања. Таква издања су најзаступљенија у Информационо-рефералном центру са читаоницом, Завичајној збирци, али их има и у другим, посебно већим огранцима, тј. тамо где постоји већа могућност да ће бити тражени и коришћени. За ову врсту фонда се може рећи да није велик, али да садржи све најпознатије и најрелевантније наслове (од националних, општих и посебних библиографија) 
који су доступни корисницима и који су, с обзиром на њихову структуру, углавном довољно заступљени. На крају, за фондове свих наших огранака се, на основу извршених анализа, добијених и приказаних резултата, може рећи да су углавном профилисани у складу са потребама локалних средина, да је највећи део тога фонда стар (два пуга више од препорука и стандарда), да у неким приградским огранцима постоје заначајна одступања у величини фонда у односу на насељеност. До повећања потребних средстава за набавку, са циљем смањења разлике између захтева стандарда и наших могућности, могуће је доћи буђењем како опште друштвене свести, тако и код оснивача, о значају неговања институционалне културе, уместо тренда смањења броја буџетских корисника у корист финансирања разних уличних и пролазних манифестација или пројеката, као и буђењем друштвене свести о значају донирања средстава институцијама културе, што је у свету већ традиција, и на крају преко ЕУ фондова за развој културе. У складу са тим и ширење спектра услуга које ће довести до тога да ГБНС постане незаобилазан јавни сервис свих својих суграђана додатно отвара и могућности за нуђење и добијање пројеката и на тај начин стицање додатних средстава финансирања.

\section{Literatura:}

1. Bibliotekarsko društvo Srbije. Predlog Standarda za javne biblioteke u Republici Srbiji. Bibliotekarsko društvo Srbije, 2007. www.bds.rs/gpage16.html (preuzeto 11. 2. 2009).

2. BISIS, https://app.bisis.rs/\#/bisis-search (preuzeto 17. 5. 2019).

3. Čukić, Leposava i Ana Ceranić. „Standardi za narodne biblioteke”. Zajednica biblioteka god. 15, br. 1-4 (1986): 38-73. (na ćirilici)

4. Gradska biblioteka u Novom Sadu. „Izveštaj o radu i poslovanju za 2018. godinu”, http://www.gbns.rs/index.php? option=com_content\&view=article\&id=156\&Item $\mathrm{id}=253$ (preuzeto 17. 5. 2019).

5. IFLA/UNESCO smernice za razvoj javnih biblioteka. Beograd: Narodna biblioteka Srbije, Biblioteka grada Beograda, 2005.

6. Miljković, Mira, Danijela Dobretić i Zdenka Valent-Belić. Nabavna politika i stanje fondova u Gradskoj biblioteci u Novom Sadu. Novi Sad (14. 12. 2009).

7. Nabavna politika - radionica, prof. dr Konrad Um, lauf - Goethe Institut Beograd, 2005. https://www.nb.rs/view_file.php?file_id=1105.

8. Perunović, Nevenka. Principi nabavne politike u bibliotekama. Beograd: Zadužbina Andrejević, 1997. 
9. Stamatović, Desanka i Leposava Čukić. „Struktura fondova narodnih biblioteka”. Zajednica biblioteka, god. 14, br. 1-4 (1986), str. 49-54. (na ćirilici)

10. Standardi za javne biblioteke u Republici Srbiji Bibliotekarskog društva Srbije 2009. http://www.gbns.rs/images/zakoni/standardi_za_javne_biblioteke.pdf (preuzeto 1. 4. 2019).

11. „Zakon o bibliotečko-informacionoj delatnosti”. Službeni glasnik RS br. 52 (2011). https://www.nb.rs/view_file.php?file_id=3047 (preuzeto 17. 5. 2019).

12. Zavod za statistiku. Struktura stanovništva po nacionalnoj ili etničkoj pripadnosti, http://www.stat.gov.rs (preuzeto 17. 5. 2017).

13. Zavod za statistiku. Struktura stanovništva po obrazovanju, http://www.stat.gov.rs (preuzeto 17. 5. 2017).

14. Zavod za statistiku. Struktura stanovništva po starosti, http://www.stat.gov.rs (preuzeto 17. 5. 2017). 
Danijela D. Dobretić

danijela.m.dobretic@gmail.com

Andrej S. Radulović

gbnovisad@gmail.com

Novi Sad City Library

\title{
ACQUISITION POLICY OF THE NOVI SAD CITY LIBRARY: OBJECTIVES, QUANTITATIVE AND QUALITATIVE CRITERIA, LEGAL REGULATIONS, AND FORMS OF ACQUISITION
}

\begin{abstract}
The paper discusses the problem of book acquisition in public libraries, with a special emphasis on the book acquisition in the Novi Sad City Library and the models how this important segment of the library operations is realized, starting from the goals of the acquisition policy, qualitative and quantitative criteria of acquisition, as well as legal regulations, guidelines, and standards that we rely on as professionals. The acquisition policy is analyzed in relation to the age structure of the population of Novi Sad, as well as the share of the population with membership in the Novi Sad City Library. Finally, legal regulations and forms of acquisition at the Library are presented, and the attention is drawn to certain problems that librarians face and how to overcome them.
\end{abstract}

Keywords: acquisition policy, quantitative and qualitative criteria, book acquisition, Novi Sad City Library.

Примљено: 9. априла 2019.

Исправке: 17. маја 2019.

Прихваћено: 31. маја 2019. 